\title{
Analisis Kapasitas Insinerator Dan TPS Di Perusahaan Pengolahan Limbah Medis Padat Nafila Mayang ${ }^{1}$, Ika Saputra, ${ }^{2}$ Alfira Sofia ${ }^{3}$ \\ Mahasiswa Magister Manajemen \\ Sekolah Pasca Sarjana Universitas Pendidikan Indonesia
}

\begin{abstract}
Abstrak
Jumlah rumah sakit dan kemudahan masyarakat dalam mengakses pelayanan kesehatan di Jawa Barat semakin meningkat, hal ini mengakibatkan jumlah limbah medis yang dihasilkan juga meningkat. Berdasarkan hal tersebut maka harus diimbangi dengan kemampuan perusahaan pengolah limbah medis padat. Tujuan dari penelitian ini adalah untuk mengoptimalkan perusahaan pengolah limbah medis padat agar dapat menampung dan mengolah limbah medis sesuai dengan permintaan. Metode deskriptif dilakukan dengan wawancara untuk mendapatkan informasi mengenai kondisi perusahaan limbah medis padat saat ini. Populasi penelitian ini adalah semua data laporan harian perusahaan yang dilaporkan pada Badan Pengawas Lingkungan Hidup Daerah (BPLHD). Sampel penelitian ini adalah data laporan harian perusahaan selama 165 hari dengan jumlah limbah medis $1.859 .572 \mathrm{~kg}$. Forecasting dilakukan untuk mengonfirmasi jumlah limbah medis dan pendapatan perusahaan. Cycle time dilakukan untuk mengetahui jumlah limbah medis yang diolah perusahaan perhari dan perjam. Berdasarkan data harian perusahaan, sebanyak $49 \%$ data menunjukan pengolahan limbah medis melebihi kapasitas mesin. Sisa limbah yang tidak diolah langsung mencapai 6,1ton. Usulan perbaikan yang dapat dilakukan oleh perusahaan adalah dengan membuat desain Tempat Penyimpanan Sementara (TPS) untuk menampung sisa limbah medis padat atau membeli mesin insinerator dengan kapasitas yang sama.
\end{abstract}

Kata Kunci: Limbah Medis, Peramalan, Kapasitas, Tempat Penyimpanan Sementara (TPS)

\section{PENDAHULUAN}

Limbah medis merupakan kategori yang penting, terutama dalam dua dekade terakhir masalah limbah medis telah menjadi isu yang paling penting ketika mempertimbangkan efek negatif dan dapat membahayakan pasien, tenaga medis, fasilitas kesehatan, masyarakat, ekosistem dan lingkungan [1].

Kemudahan masyarakat mengakses fasilitas pelayanan didukung dengan program pemerintah menyediakan pelayanan BPJS, agar masyarakat mendapatkan pelayanan kesehatan murah. Menurut Kemenkes (2016) peningkatan peserta BPJS meningkat sebesar 22,40\% dari tahun 2014 - 2016. Berikut jumlah peserta BPJS tahun 2014-2016.

Semakin banyaknya pelayanan kesehatan dan masyarakat yang sakit, maka akan semakin banyak pula limbah yang dihasilkan pelayanan kesehatan baik klinik, puskesmas, dan rumah sakit. Oleh sebab itu diperlukannya manajemen pengelolaan limbah. Pentingnya penanganan limbah rumah sakit disebabkan penanganan limbah rumah sakit yang dihasilkan tidak sama dengan limbah domestik masyarakat. Meskipun pemerintah sudah menerapkan peraturan perundang-undangan Kepmenkes No. 1204 tahun 2004 mengenai reuse, reduce, recycle (3R) tetapi masih ada kendala yang harus dihadapi yaitu tidak semua limbah dapat ditanggulangi dengan $3 R$ tersebut.
Jumlah rumah sakit yang sudah melakukan pengelolaan limbah medis sesuai standar di Indonesia adalah 10,29\% sisanya sebanyak 89,71\% masih belum melakukan pengelolaan limbah medis sesuai dengan standar. Masih kurangnya rumah sakit yang dapat mengelola limbahnya secara mandiri maka peran pihak ketiga dalam mengolah limbah sangat dibutuhkan untuk mengurangi jumlah limbah medis. Meninjau berdasarkan kasus yang dihadapi di wilayah Cirebon, dikatakan bahwa adanya kelalaian yang dilakukan oleh pihak ketiga yang secara sengaja membuang limbah medis padatnya ditempat umum dan terbuka yang seharusnya hal tersebut tidak Boleh dilakukan [10]. Berdasarkan spesifikasi insinerator tersebut Perusahaan Pengolah Limbah Medis mampu mengolah limbah medis sebesar $500 \mathrm{~kg} / \mathrm{jam}$ atau 12 ton/hari. Pembakaran dilakukan dengan 2 tahap, hal ini dilakukan untuk memastikan bahwa sudah tidak adanya sisa limbah medis padat yang terinfeksi. Jumlah pelayanan kesehatan di Indonesia semakin tahun semakin meningkat. rata-rata peningkatan rumah sakit serta tempat tidur rumah sakit yaitu sebesar $20 \%$ pada 
periode 2013 - 2016 [2]. Semakin banyaknya jumlah pelayanan kesehatan, maka jumlah limbah medis pun semakin meningkat. Berdasarkan perkiraan WHO bahwa 15\% limbah yang dihasilkan rumah sakit yang telah terkontaminasi oleh infeksi memiliki potensi yang membahayakan manusia serta lingkungan apabila manajemen pengelolaan limbahnya tidak sesuai dengan standar yang sudah ditetapkan oleh pemerintah [3]

Berdasarkan penelitian yang dilakukan EPA, insinerator merupakan teknologi terbaik yang saat ini digunakan dalam pemusnahan limbah rumah sakit dan teknologi yang paling banyak digunakan pada saat ini [4]. Namun belum banyak rumah sakit di Indonesia yang sudah mengolah limbah medis padat sesuai standar. Menurut Kemenkes RI tahun 2016 jumlah rumah sakit yang sudah melakukan pengolahan limbah medis sesuai standar adalah sebesar 10,29\%, sedangkan sisanya $89,71 \%$ belum melakukan pengolahan limbah medis sesuai standar. Oleh sebab itu, peranan pihak ketiga sangat diperlukan untuk mengolah limbah medis padat.

Salah satu perusahaan pengolah limbah medis padat adalah perusahaan yang berdiri di daerah Karawang, Jawa Barat. Berdasarkan data jumlah limbah yang diolah melebihi kapasitas mesin yang seharusnya yaitu $500 \mathrm{~kg} / \mathrm{jam}$ atau 12ton/hari. Peramalan dilakukan untuk mengkonfirmasi jumlah limbah pada periode selanjutnya. Kapasitas dilakukan untuk melihat jumlah limbah yang diolah secara optimal.

\section{KERANGKA PENELITIAN \& HIPOTESIS}

\section{A. Manajemen Operasi}

Manajemen operasi adalah serangkaian kegiatan membentuk produk atau jasa dimulai dengan input, proses, dan output [5].

\section{B. Desain Proses \& Kapasitas}

Proses adalah cara, motode, dan teknik, bagaimana sesungguhnya sumber daya, yaitu tenaga kerja, mesin, bahan dan modal yang ada, dapat diolah menjadi hasil atau produk. Suatu proses merupakan suatu rangkaian kegiatan yang dilakukan untuk menghasilkan suatu produk, berupa barang

atau jasa, ataupun gagasan, dalam rangka untuk mencapai suatu tujuan yang diharapkan. Untuk mencapai suatu tujuan, terdapat alternatif cara atau teknik dan metode yang dapat dipilih untuk digunakan.
Sehingga untuk memilih alternatif yang akan digunakan dalam menghasilkan produk, maka dibutuhkan pertimbangan yang tepat. Proses yang dipilih, yang dikaitkan dengan altenatif yang ada, haruslah dapat memberikan hasil yang efisien, terkait dengan waktu, bahan baku, dan biaya, serta mutu hasil yang dicapai. Proses penyeleksian dan perencanaan kapasitas dimulai dengan adanya input (peramalan, desain produk, dan perubahan teknologi), output (fasilitas dan perlengkapan, layout, dan desain kerja) [6].

\section{Insinerator}

Insinerator merupakan tempat pembakaran yang digunakan untuk mengolah limbah padat, yang mengkonversi materi padat (sampah) menjadi materi gas, dan abu (bottom ash dan fly ash). Proses yang dilakukan dengan cara pembakaran pada temperature lebih dari $8000 \mathrm{C}$ untuk mereduksi sampah mudah terbakar (combustible) yang sudah tidak dapat didaur ulang lagi, serta membunuh bakteri, virus, dan kimia toksik [7].

\section{Tempat Penyimpanan Sementara (TPS)}

Tempat penampungan sementara limbah medis harus dilengkapi dengan penutup, menjaga agar area penyimpanan limbah medis tidak tercampur dengan limbah non medis, membatasi akses sehingga hanya orang tertentu yang dapat memasuki area tempat penampungan, serta labeling dan pemilihan tempat yang tepat [8].

Fungsi penyimpanan ini adalah untuk mengumpulkan limbah medis sebelum dibakar untuk menjamin kesehatan dan keselamatan petugas pengelolaan limbah agar mencegah terjadinya penularan baik melalui udara, kontak langsung maupun melalui binatang. Selain itu pengelolaan yang terus menerus dijaga dengan baik dapat menunjang ketersediaan sesuai dengan kebutuhan yang diinginkan [9].

Jumlah penampungan sementara sesuai dengan kebutuhan serta kondisi ruangan. Sarana penampungan untuk limbah medis diletakkan pada tempat aman dan hygiene. Wadah penampungan yang digunakan harus tidak mudah berkarat, kedap air, memiliki tutup yang rapat, mudah dibersihkan, mudah dikosongkan atau diangkut, tidak menimbulkan bising dan tahan terhadap benda tajam dan runcing. Penampungan dilakukan agar limbah yang diangkut dapat dikelola lebih lanjut atau pembuangan akhir [11].

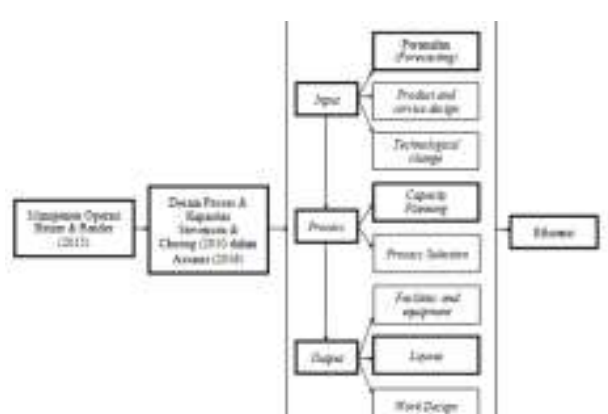


Gambar 2.2 Kerangka Pemikiran Desain Proses \& Kapasitas (Input, Process, Output) menghasilkan efisiensi perusahaan pengolah limbah medis padat

\section{METODE PENELITIAN}

Objek penelitian ini adalah kapasitas incinerator dan tempat penyimpanan sementara pada perusahaan pengolah limbah medis padat, menggunakan forecasting jumlah limbah dan jumlah pendapatan perusahaan dengan metode Pendekatan naï, Moving average, Weight Moving average, Exponential Smoothing, dan Trend Projection. Peramalan yang dilakukan dengan lima metode tersebut selanjutnya dihitung errornya dengan menggunakan MAD, MSE, dan MAPE.

Menghitung kapasitas mesin incinerator dengan metode cycle time, berdasarkan kedua metode tersebut maka dapat diketahui gap jumlah limbah medis padat yang masuk dengan kapasitas mesin yang optimal. Selanjutnya menghitung antrian limbah yang masuk dengan Model A (M/M/1): Single-Server Queuing Model with Poisson Arrivals and Exponential Service Time pada perusahaan dan memberikan usulan desain layout tempat penyimpanan sementara (TPS) digunakan untuk limbah yang mengantri.

Objek penelitian dilakukan pada salah satu perusahaan pengolah limbah medis padat daerah Karawang, Jawa Barat.

Penulisan penelitian ini menggunakan metode deskriptif bertujuan untuk mengetahui dan mampu menjelaskan karakteristik variabel yang diteliti dalam suatu variabel.

Populasi penelitian ini adalah seluruh data laporan harian perusahaan yang berisikan daftar rumah sakit, jumlah limbah yang diterima, dan sisa residu yang dibakar oleh perusahaan pengolah limbah medis yang dilaporkan pada Badan Pengawas Lingkungan Hidup Daerah (BPLHD) pada tahun.

2009 - 2016. Sampel yang digunakan dalam penelitian ini adalah data laporan harian perusahaan yang telah dipublikasi berisikan daftar rumah sakit, jumlah limbah yang diterima, dan sisa residu yang dibakar oleh perusahaan yang dilaporkan pada Badan Pengawas Lingkungan Hidup Daerah (BPLHD) selama enam bulan Juli - Desember 2016 atau selama 165 hari dengan jumlah limbah medis sebesar $1.859 .572 \mathrm{~kg}$.

Teknis analisa data menggunakan peramalan dengan analisis data kuantitatif untuk mengkonfirmasi jumlah limbah medis yang diolah oleh perusahaan, kapasitas insinerator dilakukan untuk mengetahui jumlah limbah yang diolah sesuai dengan mesin insinerator, dan antrian dilakukan untuk mengatahui jumlah limbah medis yang menunggu untuk diolah dalam mesin insinerator.

\section{HASIL DAN PEMBAHASAN}

\section{A. Peramalan}

Peramalan dilakukan dengan analisis data kuantitatif yaitu pendekatan naïf, moving average, weight moving average, exponential smoothing, dan trend linear. Perhitungan error masing - masing metode dilakukan dengan mnghitung MAD, MSE, dan MAPE. Perhitungan peramalan dilakukan dengan menggunakan QM for Windows V5. Berikut hasil rekapitulasi hasil peramalan.

\begin{tabular}{|c|c|c|c|c|c|}
\hline \multirow[b]{2}{*}{ Nenaure } & \multicolumn{5}{|c|}{ Iflete } \\
\hline & Yait & $\begin{array}{l}\text { Moning } \\
\text { Amagr }\end{array}$ & 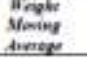 & 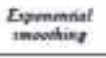 & $\begin{array}{l}\text { Iremd } \\
\text { Presinetion }\end{array}$ \\
\hline 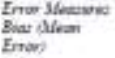 & 36 & 91,125 & 94579 & 1990.000 & 0.01 \\
\hline$\frac{\text { W. }}{\text { unE }}$ & $\begin{array}{r}3178 \\
20: 007558\end{array}$ & $\begin{array}{l}913.125 \\
1095 \times 90\end{array}$ & 3453125 & $\begin{array}{r}1913,825 \\
15566.650\end{array}$ & $\begin{array}{r}184289 \\
6338.6016\end{array}$ \\
\hline Sonded Ene & 564001 & Nid & 34 & 4 Int sou & 5006. \\
\hline 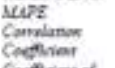 & 10396 & 0.344 & o.ents & 0.626. & 0.0. \\
\hline $\begin{array}{l}\text { Coethierer of } \\
\text { Demmananew } \\
\text { ets }\end{array}$ & & & & & $\sin 20$ \\
\hline $\begin{array}{l}\text { Foneat } \\
\text { Sot Ponad }\end{array}$ & 309917 & 309.0083 & $300 \mathrm{sns:3}$ & 310801.9 & 306.1223 \\
\hline
\end{tabular}

Metode yang paling baik digunakan dalam penelitian ini adalah dengan menggunakan metode weight moving average, karena nilai error (MAD, MSE, dan MAPE) memiliki nilai yang paling rendah.

\section{B. Kapasitas Insinerator}

Perhitungan rata - rata jumlah limbah medis yang diolah perhari dapat dilakukan dengan rumusan sebagai berikut.

$$
W=\frac{\Sigma w_{t}}{N}
$$

Ket: $W=$ Rata- rata jtmlah limbah medis perhari. $\Sigma W_{i}=J$ umlah limbah medis yang diolah mesin perhari $\mathrm{N}=$ Jumlals semua periode perhari. 


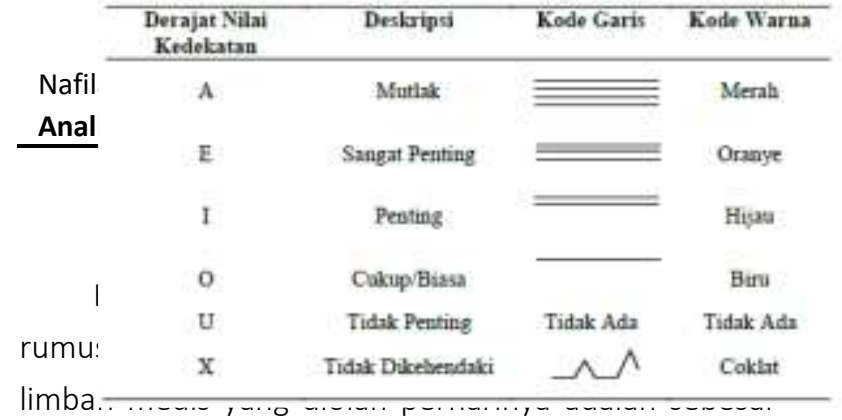

$11.270,13 \mathrm{~kg} / \mathrm{hari}$.

Rata - rata jumlah limbah medis yang diolah perjamnya dapat dilakukan dengan perhitungan sebagai berikut.

$$
c_{p i}=\frac{w_{i}}{\tau_{c}}
$$

Ket: $C p i=$ Kapasitas insinerator

$W_{i}=$ Limbah medis yang masuk

$T c=$ Siklus waktu insinerator

Berdasarkan perhitungan diatas rata - rata kapasitas insinerator pada bulan Juli - Desember 2016 adalah sebesar 469,59kg/jam. Sedangkan jumlah limbah medis yang diolah perharinya 49\% diatas kapasitas mesin insinerator.

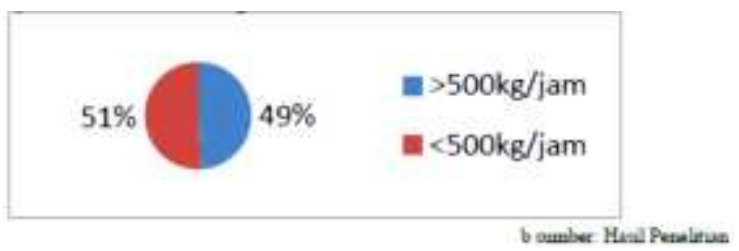

Perhitungan efektivitas kerja mesin insinerator dilakukan untuk melihat sejauh mana mesin insinerator efektif dalam membakar limbah medis padat menjadi abu, dapat dilakukan dengan menggunakan rumusan sebagai berikut.

$$
\eta=\frac{W_{\text {in }}-w_{\text {out }}}{w_{\text {in }}}
$$

Ket $: \eta=$ Efektivitas mesin insinerator

$\mathrm{W}_{\mathrm{wa}}=$ Limbah mesin yang masuk

$\mathrm{W}_{\text {out }}=$ Sisa abu pembakaran

Berdasarkan perhitungan dengan rumusan tersebut, maka diketahui bahwa nilai efektivitas insinerator adalah sebesar $90 \%$.

\section{Antrian}

Sistem antrian dengan menggunakan model (M/M/1): Single-Server Queuing Model with Poisson Arrivals and Exponential Service Time menggunakan jalur antrian tunggal atau satu stasuin pelayanan. Perhitungan antrian dilakukan dengan alat bantu QM for Windows V5.

Berdasarkan perhitungan antrian perhari, diketahui bahwa banyaknya jumlah limbah yang menumpuk pada plant adalah sebesar $6.066,55 \mathrm{~kg}$ pada tanggal 4 November 2016. Oleh sebab itu dibutuhkan tampat penyimpanan sementara (TPS) yang dapat menyimpan jumlah limbah medis yang belum diolah secara langsung.
D. Desain Layout TPS

Menentukan layout tempat penyimpanan sementara (TPS) perusahaan, dilakukan dengan menggunakan Activity Relationship Chart dan Activity Relationship Diagram. Activity Relationship Chart dan Activity Relationship Diagram merupakan metode yang dilakukan secara kualitatif, dapat dilakukan dengan beberapa tahapan.

1. Analisa Fasilitas

Input data dilakukan untuk mengumpulkan data masukan dan fasilitas. Pengumpulan data yang berkaitan dengan fasilitas dalam plant berguna agar

\begin{tabular}{|c|c|c|}
\hline No. & Fasilitas & Keterangan \\
\hline 1. & Area insinerator & Tempat mesin pembakaran limbah medis padat \\
\hline 2 & $\begin{array}{l}\text { Asea } \\
\text { penymmpanan }\end{array}$ & $\begin{array}{l}\text { Tempat penymipanan sementara (TPS) limbah } \\
\text { medis padat }\end{array}$ \\
\hline 3. & Kanter & Tempar karyawan administrast \\
\hline 4. & Tempat parkir & Digunakan unhuk parkit keudataan kecil \\
\hline 5. & Tanki air & Texpat peavimpanan air bersih \\
\hline 6. & Pos sacpan & Tempat penjagan pinta masuk plant \\
\hline 7 & PLN & Dipunakan untuk instolast listrik \\
\hline
\end{tabular}
analisa layout dilakukan dengan sebaik - baiknya.

Fasilitas yang sudah dijelaskan pada tabel 4.13 digambarkan pada layout plant perusahaan pengolah limbah medis padat dibawah ini.

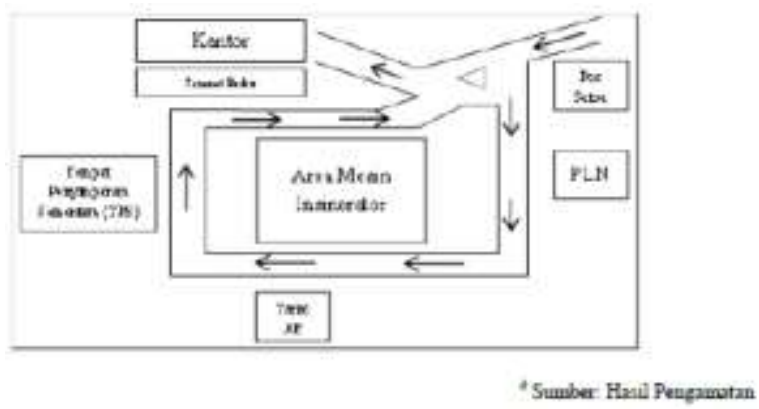

\section{Activity Relationship Chart \& Activity Relationship Diagram}

Standar penggambaran derajat aktivitas berdasarkan metode Activity Relationship Chart

\begin{tabular}{|c|c|c|c|}
\hline $\begin{array}{c}\text { Derajat Nilai } \\
\text { Kedekatan }\end{array}$ & Deskripsa & Kode Garis & Kode Waraa \\
\hline A & Mutlak & $\bar{\equiv}$ & Meral \\
\hline E & Sangat Penting & 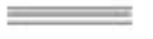 & Oranje. \\
\hline 1 & Penting & & Hijau \\
\hline o & Cokup/Btasa & & Binu \\
\hline $\mathrm{u}$ & Tidak Penting & Tidak Ada & Tidak Ada \\
\hline $\mathrm{x}$ & Tidak Dikeliendaki & $\sim \wedge$ & Coklat \\
\hline Notasi & \multicolumn{3}{|c|}{ Keterangan } \\
\hline A & \multicolumn{3}{|c|}{ Mutlak perlu didekatkan } \\
\hline $\mathrm{E}$ & \multicolumn{3}{|c|}{ Sangat penting untuk didekatkan } \\
\hline 1 & \multicolumn{3}{|c|}{ Penting untuk didekatkan } \\
\hline $\mathrm{O}$ & \multicolumn{3}{|l|}{ Cukup } \\
\hline $\mathrm{U}$ & \multicolumn{3}{|l|}{ Tidak penting } \\
\hline $\mathrm{X}$ & \multicolumn{3}{|c|}{ Tidak dikehendaki untuk berdekatan } \\
\hline
\end{tabular}
dijelaskan padat tabel dibawah ini.

\begin{tabular}{cl}
\hline No. & \multicolumn{1}{c}{ Alasan } \\
\hline 1 & Menggumakan catatan yang sama \\
2 & Mengguakan personil yang sama \\
3 & Menggunakan nuangan yang sama \\
4 & Tingkat hubungan personil
\end{tabular}


Activity Relationship Chart dilakukan untuk menganalisa hubungan antara satu departemen atau proses produksi dengan yang lainnya. Memilih hubungan mana yang paling penting untuk berdekatan satu sama lain atau bahkan berjauhan sesuai dengan derajat hubungannya masing - masing satu dengan yang lainnya.

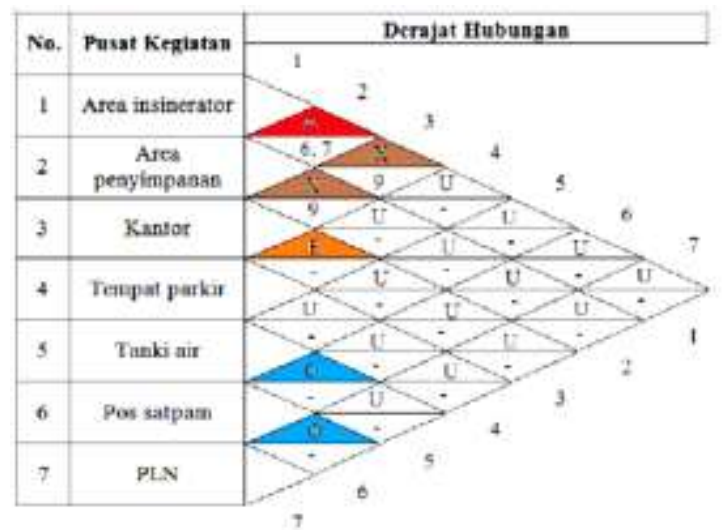

- Sumber Hail Penpanotan

Berdasarkan gambar diatas, maka dapat diketahui bahwa antara fasilitas area insinerator dengan tempat penyimpanan sementara mutlak berdekatan. Sedangkan area insinerator dan tempat penyimpanan sementara (TPS) haruslah berjauhan dengan kantor. Antara kantor dengan tempat parkiran diperlukan untuk sangat berdekatan. Pos satpam cukup berdekatan dengan instalasi listrik dan tanki air.

\begin{tabular}{|c|c|c|c|c|c|c|c|}
\hline \multirow{2}{*}{\multicolumn{2}{|c|}{ Natror dan Bagian }} & \multicolumn{6}{|c|}{ Derajat Kedekatan } \\
\hline & & $A$ & E & I & 0 & $\mathrm{~V}$ & $\mathrm{x}$ \\
\hline \multirow{2}{*}{$\frac{1}{2}$} & Area insmerator & 6.7 & $\because$ & $\because$ & $T$ & $\because$ & 9 \\
\hline & $\begin{array}{l}\text { Ares } \\
\text { penyimpanan }\end{array}$ & - & $=$ & $=$ & . & - & 9 \\
\hline 3. & Kantor & - & - & - & $\rightarrow$ & 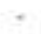 & . \\
\hline 4. & Tenapat parkir & $=$ & - & - & - & 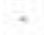 & - \\
\hline 5. & Tanki ast & - & . & . & - &. & . \\
\hline 6. & Po5 satpam & - & - & - & - & - & $=$ \\
\hline 7 & PLN & - & - & - & - & 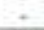 & . \\
\hline
\end{tabular}

Berdasarkan tabel diatas, maka diketahui alasan hubungan antara aktivitas, bahwa area insinerator dan tempat penyimpanan sementara (TPS) tidak dikehendaki untuk berdekatan dengan kantor dikarenakan resiko tercemarnya limbah medis padat infeksius. Tetapi area insinerator dan tempat penyimpanan sementara diharuskan untuk berdekatan karena untuk mempermudah alur pengolahan limbah medis padat. Berdasarkan Activity Relationship Chart maka dapat diketahui Activity Relationship Diagram. Berikut ini adalah Activity Relationship Diagram perusahaan limbah medis padat.

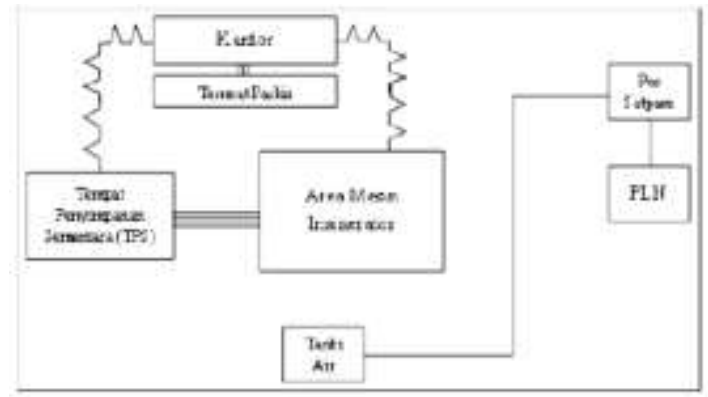

ISaber Hail Peraitian

\section{KESIMPULAN}

Berdasarkan hasil yang telah dilakukan dalam penelitian ini, maka dapat disimpulkan sebagai berikut:

1. Kondisi perusahaan pengolah limbah medis padat saat ini dilakukan dengan beberapa tahapan yaitu, pengambilan, transportasi, pengolahan limbah medis padat, dan sanitary landfill. Mesin insinerator yang digunakan oleh perusahaan pengolah limbah medis memiliki kapasitas $500 \mathrm{~kg} / \mathrm{jam}$. Jam kerja perusahaan Senin hingga Sabtu dibagi menjadi 3 shift kerja, setiap shift bekerja selama 8 jam atau 24 jam/hari. Rata - rata jumlah limbah medis yang diterima oleh perusahaan adalah sebesar 11,3 ton/hari atau $469,59 \mathrm{~kg} / \mathrm{jam}$

2. Metode yang paling baik digunakan memiliki error yang paling kecil yaitu dengan menggunakan weight moving average. Jumlah limbah dan pendapatan yang diprediksi menurun dari periode sebelumnya. Rata - rata jumlah limbah medis yang diolah oleh perusahaan masih dibawah kapasitas mesin, namun apabila dilihat lebih jauh jumlah limbah yang masuk melebihi kapasitas mesin insinerator hingga 49\%. Tingkat pembakaran mesin insinerator yang dilakukan sudah efisien.

3. Sistem antrian perhari menunjukan bahwa, namun data harian perusahaan menunjukan bahwa waktu sibuk perusahaan antara 1\% - 151\%. Sisa kelebihan limbah medis yang tidak langsung diolah dapat ditampung pada tempat penyimpanan 
sementara (TPS). Dalam menentukan TPS dilakukan dengan menggunakan metode Activity Relationship Chart (ARC) dan Activity Relationship Diagram (ARD). Berdasarkan metode tersebut maka dapat diketahui bahwa TPS dan area insinerator mutlak perlu didekatkan dan tidak dikehendaki untuk berdekatan dengan kantor dikenakan ribut, kotor, debu, dll. Penentuan bangunan TPS ditentukan berlandaskan pada Keputusan Kepala Bapedal No. 1 Tahun 1995 Tentang: Tata Cara dan Persyaratan Teknik Penyimpanan dan Pengumpulan Limbah Bahan Berbahaya dan Beracun.

\section{REKOMENDASI}

Saran yang dapat diusulkan adalah sebagai berikut.

1. Pengembangan pasar yang dituju oleh perusahaan pengolah limbah medis padat harus diimbangi dengan kapasitas yang dimiliki oleh perusahaan pengolah limbah medis padat. Dengan membangun tempat penyimpanan sementara (TPS) perusahaan agar dapat menampung limbah medis lebih banyak.

2. Kelebihan kapasitas limbah medis padat yang diolah dengan kapasitas mesin insinerator yang semestinya dapat mengakibatkan munculnya masalah baru bagi perusahaan limbah medis padat seperti maintenance mesin insinerator yang mengakibatkan mesin harus berhenti pengolah limbah medis sementara waktu dan break down pada mesin insinerator. Jangka panjang yang dapat dipertimbangkan oleh perusahaan adalah dengan membeli mesin insinerator yang baru.

3. Ketaatan atas peraturan yang sudah ditetapkan oleh pemerintah dijalankan sesuai dengan Standard Operation System (SOP) yang berlaku. Sehingga perusahaan pengolah limbah medis padat tidak mendapatkan sanksi atas penumpukan limbah medis padat.

Saran bagi paneliti selanjutnya:

Memberikan usulan lainnya untuk perusahaan pengolah limbah medis padat dengan keputusan manajemen operasional yang lainnya seperti, maintenance, penjadwalan, work design, dll untuk mengembangkan usaha pengolahan limbah medis padat.

\section{DAFTAR PUSTAKA}

[1] Makajic-Nikolic, Dragana et.al. 2015. The fault tree analysis of infectious medical waste management. Journal of Cleaner Production. pp 1-9.

[2] Tim Penyusun Kementerian Kesehatan RI. 2016. Profil Kesehatan Indonesia. Diakses dari http://www.depkes.go.id/resources/.../profi I-kesehatan.../Profil-Kesehatan-Indonesia2016.pdf.

[3] World Health Organization (WHO). 2017. Health Care Waste. Diakses dari http://www.who.int/topics/medical_waste/ en/.

[4] Saragih, Jahn Leonard \& Herumurti, Welly.2013. Evaluasi Fungsi Insinerator dalam Memusnahkan Limbah B3 di Rumah Sakit TNI Dr. Ramelan Surabaya. Jurnal Teknik POMITS. Vol. 2 No. 2 ISSN:2337-3539 (2301-9271).

[5] Heizer, Jay \& Render, Barry. 2015. Manajemen Oeprasi. Jakarta: Salemba Empat.

[6] Assauri, Sofjan. 2016. Manajemen Operasi Produksi Pencapaian Sasaran Organisasi Berkesinambungan Edisi 3. Depok: PT Rajagrafindo Persada.

[7] Latief, A Sutowo. 2010. Manfaat dan Dampak Penggunaan Incinerator Terhadap Lingkungan. Jurnal Teknis ISSN 1907. Vol. 5 No. 1 pp 20-24.

[8] Reinhardt, Peter A \& Gordon, Judith G. 1991. Infectious and Medical Waste Management. Michigan, USA: Lewish Publisher inc.

[9] Paramita, Nadia. 2007. Evaluasi Pengelolaan Sampah Rumah Sakit Pusat Angkatan Darat Gatot Soebroto. Jurnal PRESIPITASI. Vol. 2 No. 1. ISSN 1907-187X.

[10]http://regional.kompas.com/read/2017/12/15/0 7383931/soal-limbah-medis-di-cirebonkadinkes-jabar-sebut-ada-kelalaian-pihakketiga. Diakses tanggal 15 Desember 2017

[11] Chandra B, 2012. Pengantar Kesehatan Lingkungan. Jakarta: Penerbit Buku Kedokteran EGC. 